\title{
Strawberry Utilization Empowerment Program in Low-Temperature Environment as a Dental Health Promotion
}

\author{
Gilang Rasuna, M. Panji Sabila, Taufan Bramantoro, Darmawan Setijanto, Achmad Zamzam \\ Department of Dental Public Health, Faculty of Dental Medicine, Universitas Airlangga, Surabaya, Indonesia
}

\section{Abstract}

\begin{abstract}
Aims: Based on the results of preliminary observations on 100 mothers in Claket, Pacet, Mojokerto, it was obtained that there is a significant association between oral hygiene with caries rate. Of the 48 participants with poor oral hygiene index (1.3-6), 26 participants (54.2\%) had caries rate that exceeded the average of the population (decay, missing, or filling on permanent teeth index $\geq 8.29$ ). This shows that participants with poor oral hygiene tend to have high levels of caries. Providing knowledge to participants about the benefits of strawberries for oral health, especially as food, that can help the process of self-cleansing and improving oral hygiene as well as how to cultivate strawberries. Subjects and Methods: The formal approach was done through cadres of Claket village, while nonformal approach was done by building interpersonal closeness to participants who took active roles in the activities. The statistical analysis for this study was done using SPSS 17 (Statistical Package for the Social Sciences) software (SPSS Inc., Chicago, Illinois). Results: There were 38 mothers who participated in this program. A group of cadres was formed for the program, namely Laskar Pelangi, consisting of four people. The cadres received 30 strawberry seeds to be distributed to the other participants and a booklet, in which one of the contained information is about strawberry plants and the means of cultivation. Conclusions: The program went well, as evidenced by the enthusiasm of the participants and cadres in each stage of the program. It can be seen from many questions from the mothers and the results in which the mothers managed to understand how to cultivate strawberries.
\end{abstract}

Keywords: Empowerment, oral hygiene, strawberry utilization

\section{INTRODUCTION}

Dental caries or tooth decay is a common oral and dental health problem among Indonesian society. Basic Health Research in 2007 conducted by Health Department of the Republic of Indonesia reported that the prevalence of Indonesian society with dental caries was $72.1 \%$, while the prevalence of the society in East Java was higher, that is, $76.2 \%$. The high incident rates of dental caries can also be counted using decay, missing, or filling on permanent teeth (DMF-T) index. DMF-T is an indicator of dental health status which indicates the amount of decays that has been experienced by a person. ${ }^{[1]}$ According to the Basic Health Research in 2013, the DMF-T index in Indonesia was 4.6, which means that in average, each person had five tooth decays. ${ }^{[2]}$

One of the factors that are directly related to the process of caries is oral hygiene. Oral hygiene is individual's skill level in maintaining the oral cavity clean and free of hard deposit (calculus) and soft deposit (debris) through daily oral

\begin{tabular}{|l|l|}
\hline \multicolumn{2}{|c|}{ Access this article online } \\
\hline Quick Response Code: & Website: \\
\hline & www.jioh.org \\
\hline & \\
\hline
\end{tabular}

and dental health care ${ }^{[3]}$ Oral hygiene highly affects the process of oral and dental health maintenance. Clean teeth, such as those free from plaque, will not develop caries. ${ }^{[4]}$

This study, which was conducted in April 2016 on 100 mothers in Pacet district, East Java, Indonesia, suggests a significant correlation between oral hygiene and caries rates. Of the 48 participants with poor oral hygiene index (1.3-6), $26(54.2 \%)$ had caries rates that exceeded the average of the population. This indicates that participants with poor oral hygiene tend to develop high caries rates. Based on the survey that was done, $51 \%$ of the respondents consumed high amount of cariogenic snack and have high DMF-T score [Table 1].

\section{Address for correspondence: Dr. Taufan Bramantoro Mayjend. Prof. Moestopo No. 47, Surabaya, East Java, Indonesia. E-mail: taufan-b@fkg.unair.ac.id}

This is an open access journal, and articles are distributed under the terms of the Creative Commons Attribution-NonCommercial-ShareAlike 4.0 License, which allows others to remix, tweak, and build upon the work non-commercially, as long as appropriate credit is given and the new creations are licensed under the identical terms.

For reprints contact: reprints@medknow.com

How to cite this article: Rasuna G, Sabila MP, Bramantoro T, Setijanto D, Zamzam A. Strawberry utilization empowerment program in low-temperature environment as a dental health promotion. J Int Oral Health 2019;11:S26-9. 
With poor oral hygiene, plaque will easily form on the teeth, which is one of the triggers of caries. ${ }^{[5]}$ Due to the plaque's pathological potential, it is necessary to prevent its accumulation on the teeth surface and gingiva. The control can be done by chewing fibrous, watery, and nutritious food, such as fruit. ${ }^{[6]}$

Strawberry fruit (Fragaria chiloensis L.) contains polyphenols consisting of ellagic acid, anthocyanin, and catechins. Catechin can prevent dental plaque formation by inhibiting the activity of glucosyltransferase enzyme and eliminating bacteria that cause caries, such as Streptococcus mutans. Strawberry also contains pectin (natural fiber) which can act self-cleaning for the teeth. ${ }^{[7]}$ In addition, the mechanical effect of the motions in chewing strawberry can clean the plaque on the teeth surface. It is when a friction occurs between the fiber of the fruit and the teeth surface. Physiological chewing process can also stimulate saliva secretion, in which saliva also takes part in naturally cleaning the teeth from debris. ${ }^{[6]}$

Strawberry should be planted in a low-temperature environment, and in Indonesia, the cultivation should be done in plateau area. ${ }^{[8]}$ The several condition suits in Pacet district. It can be seen from several people in the village cultivating strawberries in their house yards. By far, the strawberries cultivated by the people of Pacet district are only for self-consumption or for sale. They did not know the benefits of consuming strawberry for health, especially oral and dental health.

\begin{tabular}{lccc}
\hline Table 1: Crosstabulation of type of snack consumed \\
by respondents and their decay, missing, or filling on \\
$\begin{array}{l}\text { permanent teeth index score in preliminary study } \\
\text { permer }\end{array}$ \\
\hline \multicolumn{3}{c}{ DMF-T score* } & Total \\
\cline { 2 - 3 } Type of snack & $\mathbf{< 8 . 2 9}$ & $\mathbf{2 8 . 2 9}$ & \\
\hline Low amount of cariogenic (\%) & $31(63.3)$ & $18(36.7)$ & $49(100)$ \\
High amount of cariogenic (\%) & $27(52.9)$ & $24(47.1)$ & $51(100)$ \\
Total & 58 & 42 & 100 \\
\hline
\end{tabular}

*DMF-T: Decay, missing, or filling on permanent teeth

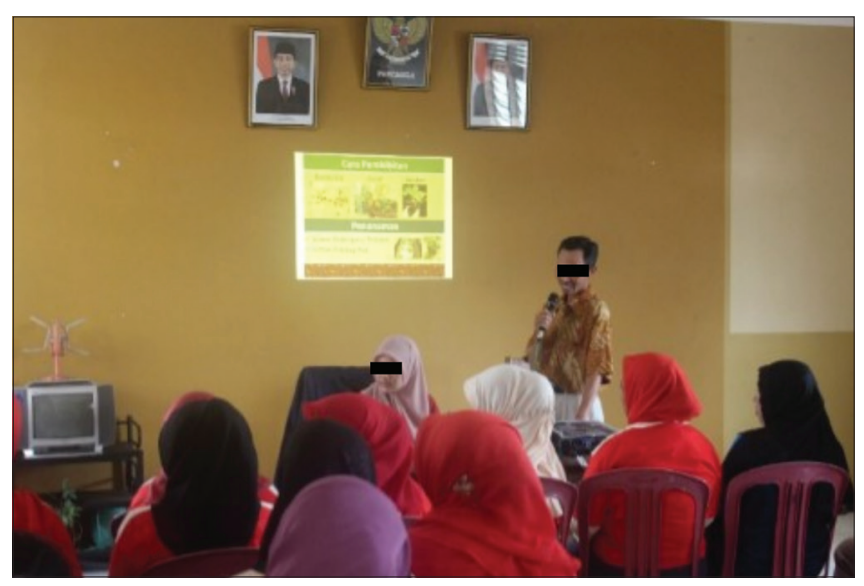

Figure 1: The speaker delivering the materials on the benefits of strawberry plants as well as how to take care of and cultivate the plants
Based on the explanation above, an empowerment program was considered necessary. Thus, this strawberry utilization program was arranged to educate the mothers in Pacet district about the benefits of strawberry for health, especially to enhance oral and dental hygiene. This program was aimed to intervene the risk factor of oral hygiene among the mothers in order to prevent the increasing rates of caries among the people in the village.

\section{Subjects and Methods}

The participants of this program are 38 mothers from Claket village, Pacet district, East Java, Indonesia. This sample size is taken from total sample, the total numbers of mothers in Claket village. This research is approved by Head of Public Health Center in area Claket village and running with Head of Town approval.

All the respondents, who were the participant in this study, had filled the informed consent that stated their willingness for intraoral examination and filling questionnaire. Ethics approval for performing this study has been obtained from the Research Ethics Committee of Faculty of Dentistry Universitas Airlangga, with the number of ethic clearance is 151/HRECC. FODM/VIII/2017.

The program was carried out through four stages. The first stage was counseling session with a source as to the benefits of strawberry and how to take care of and grow strawberry plants, followed by question and answer session afterward [Figure 1]. The second stage was forming Laskar Pelangi cadres, which consisted of four people. The third stage was distribution of 30 packs of strawberry seeds to the mother Laskar Pelangi mothers [Figure 2]. Finally, the fourth stage was evaluation for the Laskar Pelangi mothers.

Formal approach was done through the Head of Pacet Community Health Service and public figures of Claket village, such as the headman, the headmistress, and the midwife of Claket Village, by delivering the information on the benefits of strawberry for oral and dental health. The program was

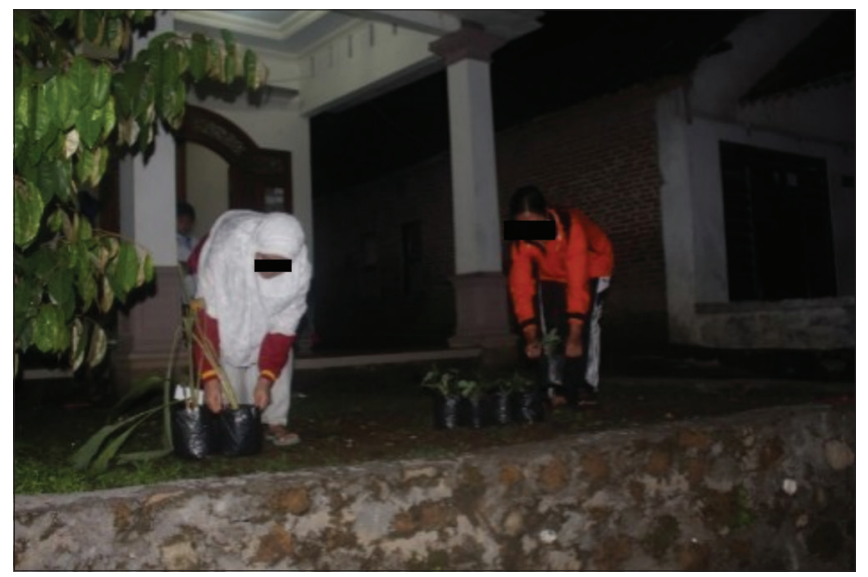

Figure 2: Distribution of strawberry seeds and fertilizer to the Laskar Pelangi mothers 
Rasuna, et al.: Strawberry utilization program for elevating oral hygiene

specifically targeted for the mothers in Claket village to enhance their oral hygiene status. Thus, the public figures were willing to provide time and place for the program.

The nonformal approach was by delivering invitations about the program through the headmistress which later was distributed to the mothers in the village. The indicator of success was that the good responses of the mothers in the village toward the program, as seen from their enthusiasm in attending the event.

\section{RESULTS}

There were 60 invitations distributed to the mothers in Claket village and 38 mothers attended the event. In the first stage, the materials on the benefits of strawberry plants as well as the means to take care of and cultivate the plants were delivered. As the results, those mothers seemed to be excited about the program. It could be seen from the number of mothers paying attention and asking questions.

In the next stage, a cadre, namely Laskar Pelangi (Laskar Peduli Kesehatan Gigi or Dental Health Care Troops) was formed, consisted of four people chosen based on their residing area. The mothers in Laskar Pelangi received 30 packs of strawberry seeds to be utilized by the mothers in Claket village along with booklets, one of them providing the information on strawberry plants and the means of strawberry cultivation.

In the last stage, the evaluation was conducted by questioning the mothers who became cadres as to how to take care of strawberry plants and the means of cultivation as well as the utilization.

\section{Discussion}

The counseling session about the benefits of strawberry was succeeded. The participants were very excited to join the counseling. Before the counseling, the participants just consumed strawberry without knowing the benefits, especially their role in maintaining oral hygiene. This is related to the statement that an empowerment program must know the problems that occur and intervene in the problem, especially to improve certain habits of the community. ${ }^{[9]}$ The program utilized strawberry as a health promotion media because it is easy to grow in low-temperature area, especially in Claket.

Health education is believed to promote active thinking and assessment of health-related issues by the public and encourage them to decide for themselves whether they want to change and in what manner. ${ }^{[10]}$ In this program, we initiate the change by conducting empowerment program. Empowerment is a good health promotion and has been describing as the "holy grail" and the main concern of health promoters. Originally, the term was applied to process which combated oppression and injustice, enabling communities to work together to increase control over their own lives and health. ${ }^{[1]}$
Community empowerment is most often viewed as a five-point continuum comprising, one of them is development of a small interest group. ${ }^{[12]}$ The group also require strong leadership to move toward achieving health outcomes. ${ }^{[13]}$ Laskar Pelangi group, as a cadre of this empowerment program, hopefully will continue the strawberry utilization program, especially the strawberry benefits for oral health and hygiene, so it can be consumed as a snack, a substitution for high amount of cariogenic snack that regularly consumed. Hence, this empowerment program can have sustainability. It is the responsibility of a dentist, a dental hygienist, and the medical worker in their area to help the cadres and make oral health programs available. ${ }^{[14]}$

\section{Conclusions}

The Strawberry Utilization Program went well, as seen from the enthusiasm of the participants and Laskar Pelangi cadres. It was proven by the many questions from the mothers who paid attention during the event.

\section{Acknowledgment}

The authors would like to thank the Department of Dental Public Health, Faculty of Dentistry, Universitas Airlangga.

\section{Financial support and sponsorship}

Nil.

\section{Conflicts of interest}

There are no conflicts of interest.

\section{REFERENCES}

1. Basic Health Research. National Report 2007. Health Research and Development Agency, Ministry of Health, Republic of Indonesia; 2008. p. 136-45.

2. Basic Health Research. National Report 2013. Health Research and Development Agency, Ministry of Health, Republic of Indonesia; 2013. p. $110-9$

3. Darby ML, Walsh MM. Dental Hygiene: Theory and Practice. $3^{\text {rd }}$ ed. St. Louis: Saunders Elsevier; 2010. p. 267.

4. Alhamda S. Dental and Oral Hygiene Status with Dental Caries Status (Study on 12-Year Age Group Students in Bukittinggi City Primary School). Public Medicine News 2011;27:108-15.

5. Anggraini F, Satari MH, Mariam MS. Bacterial inhibition test of methanolic extracts of strawberry (Fragraia x ananassa Duchesne), lime (Citrus aurantifolia), and radish (Raphanus sativus L.), towards Streptococcus sanguis ATCC 10556. Padjajaran J Dent 2018;30:1-2.

6. Central Bureau of Statistics. Production of Strawberry Fruit Plants; 2016. Available from: https://www.bps.go.id. [Last accessed on 2017 Feb 13].

7. Widyarman A, Stephanie BW, Idrus E. Strawberry extract's effects on Enterococcus faecalis and Porphyromonas gingivalis biofilms in vitro. Sci Dent J 2017;1:1-5.

8. Bartholomew LK, Markham CM, Rutler RA, Kok G, Parcel GS Planning Health Promotion Programs: An Intervention Mapping Approach. US: Jossey-Bass; 2016.

9. Catalan-Matamoros D. The Role of Media Communication in Public Health. Health Management - Different Approaches and Solutions. Spain: University of Almerica; 2011.

10. John K. Health Promotion. London: Oxford University Press; 2015. p. 31.

11. Luo W, dan Timothy DJ. An assessment of farmer's satisfaction with land consolidation performance in China. Land Use Policy 2016;61:501-10. Available from: http:/www.elsevier.com/locate/ 
Rasuna, et al.: Strawberry utilization program for elevating oral hygiene

landusepol. [Last accessed on 2017 Mar 13].

12. Sai TS, Prathap SS. Community empowerment: Holistic approach for sustainable improvements in population health. Indian J Public Health 2015;59:163-6.

13. Alrmaly BA, Assery MK. Need of oral health promotion through schools among developing countries. J Int Oral Health 2018;10:1-3.
14. Aji B, Anindita R. Analysis of Strawberry Farmer's Satisfaction for Utilization of "X" Fungicide in Pandanrejo Village, Batu City. Vol. 28. Habitat, [S.1.]; January 2018. p. 106-13. Available from: http:// www.habitat.ub.ac.id/index.php/habitat/article/ view/301; http://www. dx.doi.org/10.21776/ub.habitat. 2017.028.3.15. [Last accessed on 2018 Nov 08]. 